\title{
Pengaruh Metode Pembelajaran Cooperative Learning Tipe Group Investigation terhadap Hasil Belajar Peserta Didik SMP Negeri 1 Tinambung
}

\author{
Nurmiati $^{* 1}$, Winda Hartati ${ }^{2}$ \\ 1,2 Program Studi Pendidikan Biologi Fakultas Matematika dan Ilmu Pengetahuan Alam \\ Universitas Sulawesi Barat \\ e-mail: ${ }^{* 1}$ nurmialbugisi@gmail.com, ${ }^{2}$ zabrious@gmail.com
}

\begin{abstract}
Abstrak
Penelitian ini bertujuan untuk mengetahui pengaruh terhadap hasil belajar peserta didik (berupa nilai pretest dan posttest) pada siswa kelas VIII SMP Negeri 1 Tinambung, dengan memberikan perlakuan menggunakan pendekatan Group Investigation (GI) pada pokok bahasan sistem pencernaan. Hasil penelitian dengan judul Pengaruh metode pembelajaran Cooperative Learning tipe Group Investigation (GI) terhadap hasil belajar peserta didik kelas VIII SMP Negeri 1 Tinambung. Berdasarkan hasil perhitungan diperoleh nilai rata-rata pretest sebesar 49,13 dan rata-rata posttest sebesar 70,86. Data hasil perhitungan nilai $N$-Gain juga menunjukkan rata-rata nilai $N$-Gain untuk kelas eksperimen 0,41 yaitu 1,78 dan untuk kelas kontrol yaitu 0,30. Dengan 0,31 dan nilai = 0,05 yang menunjukkan bahwa asymp sig lebih kecil dari nilai $\alpha(0,000<0,05)$ maka HO ditolak. Data tersebut membuktikan bahwa terdapat pengaruh pendekatan metode Group Investigation terhadap hasil belajar peserta didik.
\end{abstract}

Kata kunci : Pembelajaran Koperatif, Group Investigation (GI), hasil belajar

\section{PENDAHULUAN}

Konsep pendidikan menurut undang-undang mengarah kepada pengembangan potensi peserta didik, ini berarti proses pendidikan itu harus berorientasi kepada siswa (student active learning). Masalah yang dihadapi dunia pendidikan khususnya di SMP Negeri 1 Tinambung adalah masalah lemahnya proses pembelajaran. Hingga saat ini, di SMP Negeri 1 Tinambung, terutama mata pelajaran sains biologi masih sering ditemui adanya kecenderungan meminimalkan keterlibatan peserta didik. Dominasi guru dalam proses pembelajaran menyebabkan peserta didik lebih bersifat pasif. Faktor lain yang juga tidak kalah pentingnya di dalam sebuah pembelajaran adalah faktor motivasi peserta didik itu sendiri terhadap bidang studi tertentu.

Berdasarkan permasalahan tersebut, sudah selayaknya di sekolah ini untuk menekankan kepada para guru terutama pelajaran sains biologi untuk memberikan kesempatan kepada peserta didik lebih aktif atau dapat menemukan konsep dan prinsip yang sebelumnya tidak diketahui. Pembelajaran yang dilakukan harus tepat dan dapat mengarahkan peserta didik menuju kemampuan memecahkan masalah yang berpengaruh besar terhadap hasil belajarnya. Salah satunya adalah metode Group Investigation yang didefenisikan sebagai pendekatan organisasi yang memungkinkan peserta didik untuk bekerja secara aktif dan kolabiratif dalam kelompok kecil.

Untuk meningkatkan kualitas peserta didik melalui pengajaran IPA, guru diharapkan tidak hanya memahami disiplin Ilmu IPA, tetapi hendaknya juga memahami hakikat proses pembelajaran IPA yang mencakup tiga ranah kemampuan yaitu kognitif, 
afektif dan psikomotor. Oleh karena itu, pengalaman belajar IPA harus memberikan pertumbuhan dan perkembangan siswa pada setiap aspek kemampuan tersebut dijelaskan Efi (2007)

Hal ini relevan dengan penelitian Vera Irawan Windiatmojo (2012) dalam skirpsinya berjudul Pengaruh Model Pembelajaran Kooperativ Tipe Group Investigation (GI) Terhadap Hasil Belajar Biologi Ditinjau Dari Gaya Belajar Siswa mengemukakan bahwa Model pembelajaran Group Investigation berpengaruh terhadap hasil belajar kognitif biologi.

\subsection{Jenis Penelitian}

\section{METODOLOGI PENELITIAN}

Jenis penelitian yang digunakan adalah penelitian quasi eksperiment (eksperimen semu) yaitu metode penelitian yang melakukan pengontrolan terhadap salah satu variabel.

\subsection{Waktu dan Tempat Penelitian}

Penelitian ini dilaksanakan pada bulan Oktober 2016 pada semester Ganjil tahun pelajaran 2016/2017 di SMPN 1 Tinambung. Jl poros Hoscokroaminoto No 4 Tinambung Kec. Tinambung Kab. Polewali Mandar

\subsection{Desain Penelitian}

Desain penelitian yang digunakan yaitu Pretest-Postest Two Group Design. Pada tiaptiap kelas tersebut dilakukan pretest dan posttest untuk melihat ada tidaknya perbedaan pemahaman pada kedua kelas perlakuan Pretest dilakukan sebelum pelajaran dimulai dan posttest setelah diberikan perlakuan, sehingga dapat membandingkan keadaan sebelum diberi perlakuan dan setelah diberi perlakuan.

\subsection{Populasi dan Sampel \\ 2.4.1 Populasi}

Populasi dalam penelitian ini adalah seluruh siswa SMP Negeri 1 Tinambung kelas VIII pada tahun ajaran 2016/2017.

\subsubsection{Sampel}

Sampel dalam penelitian ini adalah siswa SMP Negeri 1 Tinambung kelas VIII. kelas eksperimen yaitu VIIIb dan kelas kontrol yaitu VIIIc. Teknik pengambilan sampel dilakukan secara purposive sampling atau pengambilan sampel berdasarkan pertimbangan tertentu yang dibuat oleh peneliti sendiri, berdasarkan ciri atau sifat-sifat populasi yang sudah diketahui sebelumnya.

\subsection{Variabel Penelitian}

Variabel yang diteliti pada penelitian yaitu:

1. Variabel bebas : Metode Cooperative learning group investigation

2. Variabel terikat: Hasil belajar peserta didik

\subsection{Defenisi Oprasional Variabel}

2.6.1 Metode pembelajaran Cooperative learning GI

Group Investigation adalah penemuan yang dilakukan secara berkelompok oleh peserta didik mengalami dan melakukan percobaan dengan aktif yang memungkinkannya menemukan prinsip. Investigasi kelompok merupakan pendekatana organisasi yang memungkinkan kelas untuk bekerja secara aktif dan kolaboratif dalam kelompok kecil 
dan memungkinkan siswa untuk mengambil peran aktif dalam menentukan tujuan belajar siswa selama proses pembelajaran

\subsubsection{Hasil Belajar}

Hasil belajar merupakan Hasil penilaian terhadap kemampuan yang dimiliki peseta didik dan dinyatakan dalam bentuk angka yang diperoleh siswa dari serangkaian tes yang dilaksanakan setelah siswa mengikuti proses pembelajaran sistem pencernaan.

\subsection{Teknik Pengumpulan Data}

Teknik yang digunakan dalam penelitian ini adalah tes hasil belajar untuk mengetahui kemampuan belajar peserta didik sebelum dan setelah diajar dengan menggunakan model pembelajaran Group Investigation. Instrumen yang dikembangkan oleh peneliti adalah tes berbentuk pilihan ganda yang telah diuji cobakan untuk mengetahui validitas dan reliabilitas. Instrumen ini berupa pre-test dan post-test, pre-test diberikan kepada peserta didik pada awal pertemuan (sebelum diberikan materi) yang terdiri dari 40 item dan post-test diberikan pada pertemuan terakhir dan juga terdiri dari 40 item.

\subsection{Instrumen Penelitian}

Instrumen ini dijadikan acuan untuk mengetahui kemampuan atau prestasi siswa dalam pretest dan posttest. Dengan mengerjakan soal pilihan ganda yang berjumlah 40 (empat puluh) butir soal.

\subsubsection{Validitas}

Untuk menghitung validitas item peneliti menggunakan SPSS dengan rumus Korelasi Product Moment pearson karena skor butir soal yang diukur bersifat objektif (Pilihan Ganda).

$$
\begin{aligned}
& r_{X Y}=\frac{n \sum X Y-\sum X \sum Y}{\sqrt{n \sum X^{2}-\left(\sum X\right)^{2} \sqrt{n \sum Y^{2}-\left(\sum Y\right)^{2}}}} \\
& r_{x y}=\text { Koefisien korelasi antara variabel } \mathrm{X} \text { dan variabel } \mathrm{Y} \\
& \sum x y=\text { Jumlah perkalian antara variabel } \mathrm{x} \text { dan } \mathrm{Y} \\
& \sum x^{2}=\text { Jumlah dari kuadrat nilai X } \\
& \sum y^{2}=\text { Jumlah dari kuadrat nilai } Y \\
& \left(\sum x\right)^{2}=\text { Jumlah nilai X kemudian dikuadratkan } \\
& \left(\sum y\right)^{2}=\text { Jumlah nilai Y kemudian dikuadratkan }
\end{aligned}
$$

\subsubsection{Reliabilitas}

Untuk menghitung realibilitas peneliti menggunakan SPSS dengan rumus Alpha Cronbach karena skor butir soal yang akan diujikan berbentuk soal objektif (pilihan Ganda). Rumus Alpha Cronbach yaitu

$$
\alpha=\frac{k}{k-1}\left(1-\frac{\sum s j^{2}}{s x^{2}}\right)
$$

$\alpha=$ Koefisien reliabilitas Alpha Cronbach

$\mathrm{k}=$ Jumlah item pertanyaan yang diuji

$\mathrm{Sj}=$ Jumlah varians skot item 


$$
\mathrm{Sx}=\text { Varians skor-skor tes (seluruh item } \mathrm{K})
$$

Jika alpha $>0,90$ maka reliabilitas sempurna

Jika alpha antara $0,70-0,90$ maka reliabilitas tinggi

Jika alpha antara $0,50-0,70$ maka reliabilitas moderat

Jika alpha $<0,50$ maka reliabilitas rendah

Untuk mengetahui apakah validitas soal tersebut signifikan, maka bandingkan dengan nilai tabel person product moment pada $\mathrm{N}$ dan signifikan $5 \%$

$$
\begin{aligned}
& r_{x y} \geq \gamma_{\text {tabel }}, \text { item dinyatakan valid } \\
& r_{x y}<\gamma_{\text {tabel }}, \text { item dinyatakan drop }
\end{aligned}
$$

\subsubsection{Prosedur Penelitian}

Adapun tahap-tahap dalam prosedur penelitian adalah sebagai berikut :

1. Tahap perencanaan

2. Tahap pelaksanaan

3. Tahap evaluasi

\subsection{Teknik Analisis Data}

\subsubsection{Statistik Deskriftif}

Untuk mengkategorikan tingkat hasil belajar biologi peserta didik digunakan interval nilai sebagai berikut:

Tabel 1 Penskoran hasil belajar siswa pada aspek kognitif

\begin{tabular}{|c|c|c|}
\hline No & Interval Skor & Keterangan \\
\hline 1. & $81-100$ & Sangat Tinggi \\
2. & $66-80$ & Tinggi \\
3. & $56-65$ & Sedang \\
4. & $41-55$ & Rendah \\
5. & $0-40$ & Sangat Rendah \\
\hline
\end{tabular}

\subsubsection{Statistik Inferensial}

Sugyono (2006) menjelaskan bahwa statistik inferensial adalah statistik yang berkenaan dengan cara penarikan kesimpulan berdasarkan data yang diperoleh dari sampel untuk menggambarkan karakteristik atau ciri dari suatu populasi. Pada statistik inferensial dilakukan pengujian hipotesis dan pendugaan mengenai karakteristik (ciri) dari suatu populasi seperti mean dan uji T. Untuk menghitung statistik inferensial maka peneliti menggunakan rumus SPSS dengan rumus sebagai berikut :

\subsubsection{Uji Normalitas Data}

Pengujian normalitas terhadap data hasil belajar dilakukan dengan menggunakan sistem Statistical Package for Social Sciense (SPSS) versi 23. Pengujian normalitas ini bertujuan untuk mengetahui apakah data hasil belajar peserta didik yang diteliti berasal dari populasi yang berdistribusi normal atau tidak.

\subsubsection{Normal Gain}

Herlanti (2008) menjelaskan bahwa gain menunjukan peningkatan pemahaman atau penguasaan konsep siswa setelah pembelajaran dilakukan. Rumusnya: 


$$
N \text { gain }=\frac{\text { postest }- \text { pretest }}{\text { skor ideal }- \text { pretest }}
$$

$$
\begin{aligned}
& \text { g-tinggi }=\text { nilai }>0.70 \\
& \text { g-sedang }=\text { nilai } 0.30-0.70 \\
& \text { g-rendah }=\text { nilai }<0.30
\end{aligned}
$$

\subsubsection{Uji Homogenitas}

Dilakukan dengan menggunakan sistem Statistical Package for Social Sciense (SPSS) versi 23. Pengujian homogenitas ini bertujuan untuk mengetahui data dalam penelitian ini memiliki varians yang sama (homogen) atau tidak.

\subsubsection{Uji-t pada ranah kognitif digunakan untuk menguji Hipotesis}

Uji hipotesis dilakukan untuk melihat perbedaan hasil tes siswa dari kelompok eksperimen dan kelompok kontrol. Dengan kriteria pengujian hipotesis $\mathrm{H}_{0}$ ditolak dan $\mathrm{H}_{1}$ diterima jika Sig. $<\alpha$ begitu pula sebaliknya $\mathrm{H}_{0}$ diterima dan $\mathrm{H}_{1}$ ditolak jika Sig. $>\alpha$.

\section{HASIL DAN PEMBAHASAN}

\subsection{Deskripsi Data}

\subsubsection{Analisis Deskriptif data Pretest kelas kontrol dan kelas eksperimen}

Untuk memberikan gambaran yang lebih jelas, maka deskripsi data Pretest kelas kontrol dan eksperimen dibuat diagram batang sebagai berikut:

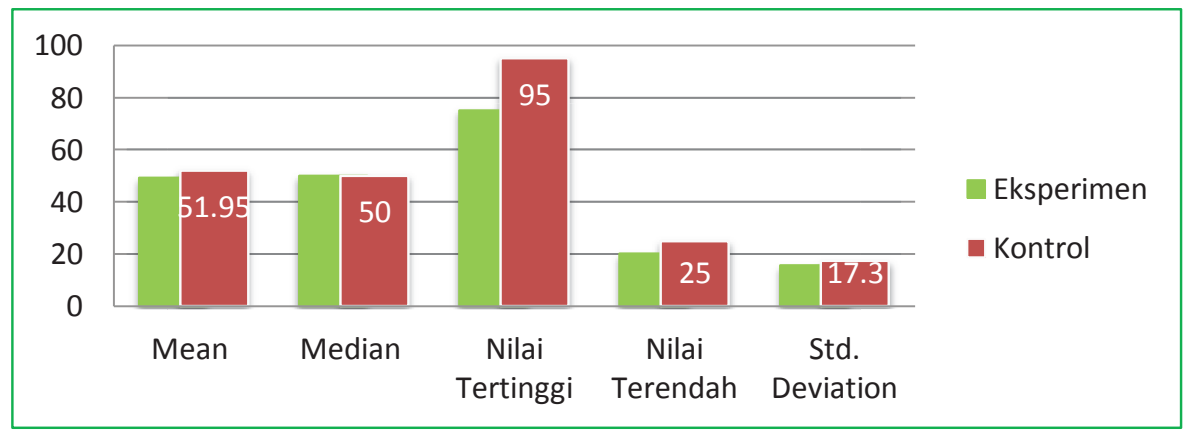

Gambar 1 Diagram batang Pretest kelas Kontrol dan kelas Eksperimen.

Berdasarkan gambar 1 diperoleh bahwa nilai mean pada kelas kontrol lebih besar dibanding dengan kelas eksperimen, nilai median kelas kontrol dan kelas eksperimen sama, nilai tertinggi dan nilai terendah kelas kontrol lebih besar daripada kelas eksperimen, dan nilai standar deviation kelas kontrol lebih tinggi dari kelas eksperimen. Dari hasil analisis menunjukkan bahwa skor Pretes yang diperoleh pada kelas Eksperimen dan kelas Kontrol tidak ada perbedaan secara signifikan.

\subsubsection{Analisis Deskriptif data Postest kelas kontrol dan kelas eksperimen}

Untuk memberikan gambaran yang lebih jelas, maka deskripsi data Postest kelas kontrol dan eksperimen dibuat diagram sebagai berikut: 


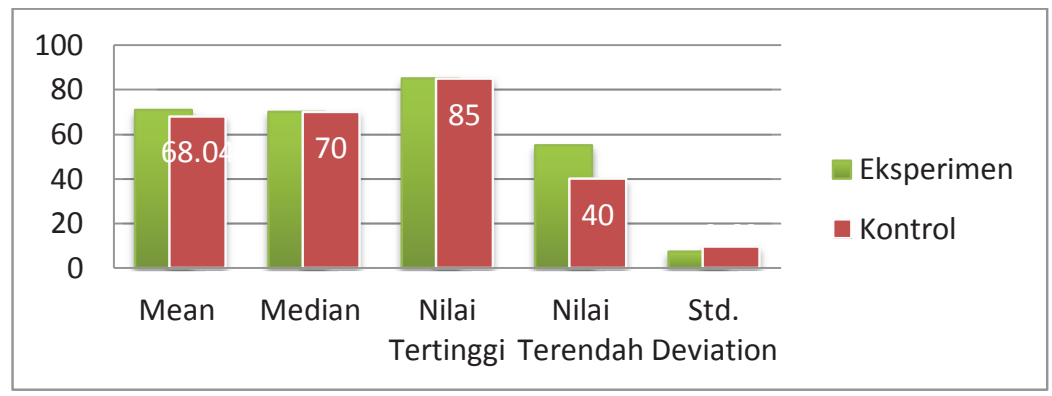

Gambar 2 Diagram batang Postest kelas Kontrol dan kelas Eksperimen.

Berdasarkan gambar 2 diperoleh bahwa nilai mean pada kelas eksperimen lebih besar dibanding dengan kelas kontrol, nilai median dan nilai tertinggi kelas kelas eksperimen dan kelas kontrol sama, nilai terendah kelas eksperimen lebih tinggi dari pada kelas kontrol, dan nilai standar deviation kelas kontrol lebih tinggi dari kelas eksperimen. Dari hasil analisis menunjukkan bahwa skor Posttest yang diperoleh pada kelas Eksperimen dan kelas Kontrol ada perbedaan secara signifikan, yaitu skor posttest yang diperoleh pada kelas eksperimen lebih besar dari pada skor posttest yang diperoleh kelas kontrol.

\subsection{Deskripsi pretest dan posttest kelas control}

Deskripsi kelas kontrol adalah kelas pembanding dengan konsep yang tetap, tidak diberikan perubahan atau perlakuan dalam pelaksanaannya. Dalam hal ini kelas VIIIB dengan menggunakan model konvensional sebagai sarana dalam konsep sistem pencernaan.

\subsubsection{Pretest kelas control}

Distibusi pretest kelas kontrol dapat dilihat pada tabel 2 dibawah ini.

Tabel 2 Distribusi Frekuensi Prettest kelas kontrol

\begin{tabular}{|c|c|c|c|c|}
\hline No & Kelas Interval & Frekuensi $(f i)$ & Titik Tengah $(X i)$ & $f i \times X i$ \\
\hline 1 & $25-36$ & 5 & 30,5 & 152,5 \\
\hline 2 & $37-48$ & 7 & 42,5 & 297,5 \\
\hline 3 & $49-60$ & 6 & 54,5 & 327 \\
\hline 4 & $61-72$ & 4 & 66,5 & 266 \\
\hline 5 & $73-84$ & 1 & 78,5 & 78,5 \\
\hline 6 & $85-96$ & 1 & 90,5 & 90,5 \\
\hline \multicolumn{2}{r|}{ Jumlah } & 24 & & 944,2 \\
\hline
\end{tabular}

Berdasarkan tabel tersebut diperoleh rata-rata 39,3. Dengan nilai 25-36 sebanyak 5 orang, 37-48 sebanyak 7 orang, 49-60 sebanyak 6 orang, 61-72 sebanyak 4 orang, 73-84 dan 85-96 sebanyak 1 orang. Kemudian peneliti menentukkan kategorisasi, dimana kategorisasinya diperoleh dari penilaian hasil belajar kelas VIII B SMP Negeri 1 Tinambung.

\subsubsection{Posttest kelas kontrol}

Distibusi pretest kelas kontrol dapat dilihat dengan perhitungan yang ada pada lampiran B.6, dengan tabel 3 dibawah ini. 
Tabel 3Distribusi Frekuensi Posttest kelas kontrol

\begin{tabular}{|c|c|c|c|c|}
\hline No & Interval Skor & Frekuensi $(f i)$ & Titik Tengah $(X i)$ & $f i \times X i$ \\
\hline 1 & $40-47$ & 1 & 43,5 & 43,5 \\
\hline 2 & $48-55$ & 1 & 51,5 & 51,5 \\
\hline 3 & $56-63$ & 4 & 59,5 & 238 \\
\hline 4 & $64-71$ & 12 & 67,5 & 810 \\
\hline 5 & $72-79$ & 2 & 75,5 & 151 \\
\hline 6 & $80-87$ & 4 & 83,5 & 334 \\
\hline & Jumlah & 24 & & 1628 \\
\hline
\end{tabular}

Berdasarkan tabel tersebut diperoleh rata-rata 67.8. Dengan nilai 40-47 dan 48-55 sebanyak 1 orang, 56-63 sebanyak 4 orang, 64-71 sebanyak 12 orang 72-79 sebanyak 2 orang, dan 80-87 sebanyak 4 orang. Kemudian peneliti menentukkan kategorisasi, dimana kategorisasinya diperoleh dari penilaian hasil belajar kelas VIII B SMP Negeri 1 Tinambung.

Untuk mempermudah mengetahui kemampuan peserta didik pada kelas kontrol, maka dibuat tabel kategorisasi.

Tabel 4 Kategori Tingkat Penguasaan Hasil Belajar Kelas Kontrol

\begin{tabular}{|c|c|c|c|c|c|}
\hline \multirow{2}{*}{ Kelas Interval } & \multicolumn{2}{|c|}{ Frekuensi } & \multicolumn{2}{c|}{ Persentase (\%) } & \multirow{2}{*}{ Kategori } \\
\cline { 2 - 5 } & pretest & postest & pretest & postest & \\
\hline $81-100$ & 1 & 1 & 4.2 & 4.2 & Sangat Tinggi \\
\hline $66-80$ & 5 & 12 & 20.8 & 50 & Tinggi \\
\hline $56-65$ & 2 & 9 & 8.3 & 37.5 & Sedang \\
\hline $41-55$ & 9 & 1 & 37.5 & 4.2 & Rendah \\
\hline $0-40$ & 7 & 1 & 29.2 & 4.2 & Sangat Rendah \\
\hline Jumlah & 24 & 24 & 100 & 100 & \\
\hline
\end{tabular}

\subsection{Deskripsi pretest dan posttest kelas eksperimen}

\subsubsection{Pretest kelas eksperimen}

Distibusi pretest kelas kontrol dapat dilihat pada tabel 5 di bawah ini.

Tabel 5 Distribusi Frekuensi Prettest kelas eksperimen

\begin{tabular}{|c|c|c|c|c|}
\hline $\mathrm{N}$ & Interval & \multirow{2}{*}{ Frekuensi $(f i)$} & Titik Tengah $(X i)$ & $f i \times X i$ \\
\hline & Skor & 2 & 24,5 & 49 \\
\hline 1 & $20-29$ & 2 & 34,5 & 138 \\
\hline 2 & $30-39$ & 4 & 44,5 & 133,5 \\
\hline 3 & $40-49$ & 3 & 54,5 & 381,5 \\
\hline 4 & $50-59$ & 7 & 64,5 & 258 \\
\hline 5 & $60-69$ & 4 & 74,5 & 223,5 \\
\hline 6 & $70-79$ & 3 & & 1183,5 \\
\hline \multicolumn{2}{|r|}{ Jumlah } & 23 & & \\
\hline
\end{tabular}

Berdasarkan tabel tersebut diperoleh rata-rata 51,5. Dengan nilai 20-29 sebanyak 2 orang, 30-39 sebanyak 4 orang, 40-49 sebanyak 3 orang 50-59 sebanyak 7 orang, dan 60-69 sebanyak 4 orang. Dan 70-79 sebanyak 3 orang Kemudian peneliti menentukkan kategorisasi, dimana kategorisasinya diperoleh dari penilaian hasil belajar kelas VIII C SMP Negeri 1 Tinambung. 


\subsubsection{Posttest kelas eksperimen}

Distibusi postest kelas eksperimen dapat dilihat pada tabel 6 dibawah ini.

Tabel 6 Distribusi Frekuensi Posttest kelas eksperimen

\begin{tabular}{|c|c|c|c|c|}
\hline No & Interval Skor & Frekuensi $(f i)$ & Titik Tengah $(X i)$ & $f i \times X i$ \\
\hline 1 & $55-59$ & 1 & 57 & 57 \\
\hline 2 & $60-64$ & 1 & 62 & 62 \\
\hline 3 & $65-69$ & 6 & 67 & 402 \\
\hline 4 & $70-74$ & 6 & 72 & 432 \\
\hline 5 & $75-79$ & 4 & 77 & 308 \\
\hline 6 & $80-85$ & 5 & 82 & 410 \\
\hline & Jumlah & 23 & & 1671 \\
\hline
\end{tabular}

Berdasarkan tabel tersebut diperoleh rata-rata 72,7. Dengan nilai 55-59 dan 60-64 sebanyak 1 orang, 65-69 dan 70-74 sebanyak 6 orang, 75-79 sebanyak 4 orang dan 80-85 sebanyak 5 orang, Kemudian peneliti menentukkan kategorisasi. dimana kategorisasinya diperoleh dari penilaian hasil belajar kelas VIII C SMP Negeri 1 Tinambung.

Untuk mempermudah mengetahui kemampuan peserta didik pada pokok bahasan sistem pencernaan pada manusia kelas eksperimen, maka dibuatkan tabel kategorasi. Adapun rincian tersebut meliputi lima kategori yaitu: sangat tinggi, tinggi, sedang, rendah dan sangat rendah. Untuk lebih jelasnya dapat dilihat pada tabel 7 berikut:

Tabel 7 Kategori Tingkat Penguasaan Hasil Belajar Kelas Eksperimen

\begin{tabular}{|c|r|r|r|r|c|}
\hline \multirow{2}{*}{$\begin{array}{c}\text { Kelas } \\
\text { Interval }\end{array}$} & \multicolumn{2}{|c|}{ Frekuensi } & \multicolumn{2}{|c|}{ Persentase (\%) } & \multirow{2}{*}{ Kategori } \\
\cline { 2 - 5 } & pretest & postest & pretest & posttest & \\
\hline $81-100$ & 0 & 1 & 0 & 4.3 & Sangat Tinggi \\
\hline $66-80$ & 3 & 14 & 13.1 & 61 & Tinggi \\
\hline $56-65$ & 4 & 7 & 17.4 & 30.4 & Sedang \\
\hline $41-55$ & 9 & 1 & 39.1 & 4.3 & Rendah \\
\hline $0-40$ & 7 & 0 & 30.4 & 0 & Sangat Rendah \\
\hline Jumlah & 23 & 23 & 100 & $100 \%$ & \\
\hline
\end{tabular}

Hal ini menunjukkan bahwa terdapat pengaruh positif penggunaan metode Group Investigation terhadap hasil belajar

\subsection{Tehnik Analisis Data.}

\subsubsection{Data Nilai N-Gain}

Setelah diperoleh data nilai pretest dan posttest masing-masing peserta didik kemudian dilakukan perhitungan Normal Gain (N-gain). Setelah dilakukan pengolahan data, diperoleh rata-rata $\mathrm{N}$-gain yang dapat dilihat pada tabel berikut.

Tabel 8 Hasil Rata- rata N-Gain Kelas Eksperimen dan Kelas Kontrol

\begin{tabular}{|c|c|c|c|c|}
\hline \multirow{2}{*}{ Data } & \multicolumn{2}{|c|}{ N-Gain } & \multicolumn{2}{c|}{ Persentase } \\
\cline { 2 - 5 } & Eksperimen & Kontrol & Eksperimen & Kontrol \\
\hline Tinggi & 0 & 0 & 0 & 0 \\
\hline Sedang & 20 & 12 & 86.95 & 50 \\
\hline Rendah & 3 & 12 & 13.04 & 50 \\
\hline Rata-rata & 0.41 & 0.30 & 1.78 & 1.30 \\
\hline
\end{tabular}




\begin{tabular}{|l|l|l|l|}
\hline Jumlah peserta didik & 23 & 24 & \\
\hline
\end{tabular}

Berdasarkan hasil pengolahan data rata nilai N-Gain dapat di simpulkan bahwa rata-rata $\mathrm{N}$-gain kelas Eksperimen 0.41 dan rata-rata $\mathrm{N}$-gain kelas Kontrol 0.30. dengan peningkatan nilai $1.30 \%$ untuk kelas kontrol dan $1.78 \%$ untuk kelas eksperimen. Hal tersebut menunjukkan bahwa pemahaman atau penugasan konsep peserta didik kelas Eksperimen lebih tinggi dibandingkan peserta didik kelas kontrol setelah dilakukan perlakuan yang berbeda.

\subsubsection{Uji Normalitas}

Uji normalitas yaitu, pengujian yang dilakukan untuk dapat mengetahui data tersebut berdistribusi normal atau tidak. Uji normalitas dilakukan pada kedua kelas yaitu eksperimen VIIIC dan kelas kontrol VIIIB. Berdasarkan data yang ada, hasil uji normalitas data penelitian menggunakan aplikasi SPSS 23 for windows dapat dilihat pada tabel dibawah ini.

1. Kelas Eksperimen

Tabel 9 Hasil Uji Normalitas kelas Eksperimen

\begin{tabular}{|c|c|c|c|c|c|}
\hline \multirow{2}{*}{ Variabel } & \multirow{2}{*}{$\begin{array}{c}\mathrm{N} \\
\text { sampel }\end{array}$} & \multicolumn{2}{|c|}{ Signifikan } & \multirow[b]{2}{*}{$\alpha$} & \multirow{2}{*}{ Kesimpulan data } \\
\hline & & Pretest & Posttest & & \\
\hline $\begin{array}{l}\text { Hasil belajar kelas } \\
\text { eksperimen }\end{array}$ & 23 & 0.542 & 0.342 & 0.05 & terdistribusi normal \\
\hline
\end{tabular}

Berdasarkan tabel diatas, bahwa nilai Sig Pretest sebesar 0.542 dan nilai posttest sebesar 0.342 dengan nilai $\alpha=0.05$ diperoleh nilai Sig untuk Pretest lebih besar daripada nilai $\alpha$ $(0.542>0.05)$ dan untuk Posttest juga diperoleh nilai Sig lebih besar daripada nilai $\alpha$ $(0.342>0.05)$. berdasarkan data tersebut dapat disimpulkan bahwa ke dua data berdistribusi normal.

2. Kelas Kontrol

Uji normalitas skor tes hasil belajar kelas Kontrol, hasilnya adalah sebagai berikut .

Tabel 10 Hasil Uji Normalitas kelas Kontrol

\begin{tabular}{|c|c|c|c|c|c|}
\hline \multirow[b]{2}{*}{ Variabel } & \multirow{2}{*}{$\begin{array}{c}\mathrm{N} \\
\text { sampel }\end{array}$} & \multicolumn{2}{|c|}{ Signifikan } & \multirow[b]{2}{*}{$\alpha$} & \multirow[b]{2}{*}{ Kesimpulan data } \\
\hline & & Pretest & Posttest & & \\
\hline Hasil belajar kelas Kontrol & 24 & 0.388 & 0.095 & 0.05 & terdistribusi normal \\
\hline
\end{tabular}

Berdasarkan tabel diatas, nilai Sig Pretest sebesar 0.388 dan nilai posttest sebesar 0.095 dengan nilai $\alpha=0.05$ diperoleh nilai Sig untuk pretest lebih besar daripada nilai $\alpha$ $(0.388>0.05)$ dan untuk Posttest juga diperoleh nilai Sig lebih besar daripada nilai $\alpha$ $(0.095>0.05)$. berdasarkan data tersebut dapat disimpulkan bahwa ke dua data berdistribusi normal.

\subsubsection{Uji Homogenitas}

\subsubsection{Uji Homogenitas Pretest}

Hasil penghitungan uji homogenitas data Pretest pada kelas eksperimen dan kontrol, diperoleh nilai signifikan Pretest kelas kontrol dan eksperimen sebesar 0.652 dengan nilai $\alpha=0.05$ maka diperoleh nilai $0.652>0.05$. Hal ini menunjukkan bahwa sampel tersebut berasal dari populasi yang berdistribusi homogen dengan menggunakan perhitungan SPSS 23 for windows. Dapat dilihat pada tabel 4.12 berikut. 
Tabel 11 Hasil uji Homogenitas Data Prettest kelas Eksperimen dan Kontrol.

\begin{tabular}{|c|c|c|c|}
\hline $\mathrm{N}$ & kelas Kontrol dan Eksperimen & $\alpha$ & Kesimpulan \\
\hline 47 & 0.652 & 0.05 & Data berdistribusi homogeny \\
\hline
\end{tabular}

\subsubsection{Uji Homogenitas Posttest}

Hasil penghitungan uji homogenitas data Posttest antara kelas Eksperimen dan kelas Kontrol, diperoleh nilai signifikan Posttest kelas Eksperimen dan Kontrol sebesar 0.439 dengan nilai $\alpha=0.05$ maka diperoleh nilai $0.439>0.05$. Hal ini menunjukkan bahwa sampel tersebut berasal dari populasi yang berdistribusi homogen. Dapat dilihat pada tabel berikut:

Tabel 12 Hasil uji Homogenitas data Posttest kelas Eksperimen dan Kontrol.

\begin{tabular}{|c|c|c|l|}
\hline $\mathrm{N}$ & kelas Kontrol dan Eksperimen & $\alpha$ & \multicolumn{1}{c|}{ Kesimpulan } \\
\hline 47 & 0.439 & 0.05 & $\begin{array}{l}\text { Data berdistribusi } \\
\text { homogeny }\end{array}$ \\
\hline
\end{tabular}

\subsubsection{Uji Hipotesis}

Pengujian hipotesis ini dilakukan setelah uji normalitas dan uji homogenitas yang menujukkan hasil dari kedua kelompok pengujian tersebut bahwa sampel berdistribusi normal dan homogen. Uji hipotesis dilakukan untuk mengetahui ada pengaruh yang signifikan sebelum dan sesudah diajar dengan metode group investigation dari kelas eksperimen dan metode ceramah di kelas kontrol. Untuk menguji hipotesis data penelitian menggunakan aplikasi SPSS.

Tabel 13 Hasil uji korelasi

\begin{tabular}{|c|c|c|c|}
\hline & $\mathrm{N}$ & Correlation & Sig \\
\hline Eksperiman Pretest dan posttes & 23 & 0.624 & 001 \\
\hline KontrolPretest dan posttes & 24 & 0.561 & 003 \\
\hline
\end{tabular}

Berdasarkan tabel 13 diperoleh nilai $\mathrm{r}$ eksperimen $=0.624$, dan nilai $\mathrm{r}$ kontrol adalah 0.561 , berarti $r \neq 0$, jadi dapat disimpulkan bahwa Ho di tolak dan H1 diterima. Artinya terdapat pengaruh yang signifikan antara hasil belajar setelah diajar menggunakan metode Group Investigation. Selanjutnya pada Sig eksperimen $0.01(\alpha=$ $0.05)$ berarti $\mathrm{Sig}<0,05$, dan Sig kontrol $0,03(\alpha=0.05)$ artinya Sig $<0.03$, dapat disimpulkan bahwa ada hubungan antara pretest dan posttes kelas eksperimen, dan pretest dan posttest kelas kontrol. Untuk lebih jelas hasil uji hipotesis dapat dilihat pada tabel dibawah ini:

\begin{tabular}{|ll|c|c|c|c|c|}
\hline \multicolumn{2}{|c|}{} & & $\mathrm{N}$ \\
Variabel & & $\begin{array}{c}\text { Nilai } \\
\mathrm{t}\end{array}$ & signifikan & $\begin{array}{c}\text { Nilai } \\
\alpha\end{array}$ & Kesimpulan data \\
\hline $\begin{array}{l}\text { Hasil belajar } \\
\text { eksperimen }\end{array}$ & kelas & 23 & $\begin{array}{c}- \\
8.411\end{array}$ & 0.000 & 0.05 & $\begin{array}{l}\text { Terdapat pengaruh lebih } \\
\text { besar di kelas ekperimen }\end{array}$ \\
\hline $\begin{array}{l}\text { Hasil belajar } \\
\text { control kelas }\end{array}$ & 24 & $\begin{array}{c}- \\
5.684\end{array}$ & 0.000 & 0.05 & $\begin{array}{l}\text { Terdapat pengaruh lebih } \\
\text { besar di kelas ekperimen }\end{array}$ \\
\hline
\end{tabular}

Berdasarkan hasil uji hipotesis pada nilai signifikan $0.000<0.05$ maka menunjukkan ada perbedaan antara prettes dan posstest baik di kelas eksperimen maupun di kelas 
kontrol. Sedangkan nilai $\mathrm{t}$ eksperimen adalah -8.411 dan nilai $\mathrm{t}$ kontrol -5.684 menunjukkan bahwa nilai $-8.411<-5.683$ maka kesimpulan adalah lebih besar pengaruh di kelas eksperimen dibanding dengan kelas kontrol.

\section{KESIMPULAN}

Berdasarkan hasil penelitian dan pembahasan dapat disimpulkan bahwa dari hasil pengolahan data rata nilai N-Gain yang dapat di simpulkan bahwa rata-rata N-gain kelas Eksperimen 0.41 dan rata-rata $\mathrm{N}$-gain kelas Kontrol 0.30. dengan peningkatan nilai 1.30\% untuk kelas kontrol dan $1.78 \%$ untuk kelas eksperimen. Hal tersebut menunjukkan bahwa pemahaman atau penugasan konsep peserta didik kelas Eksperimen dengan menggunakan metode Group Investigation lebih tinggi dibandingkan peserta didik kelas kontrol setelah dilakukan perlakuan yang berbeda. Hal ini dapat disimpulkan bahwa terdapat pengaruh pengunaan metode Group Investigation (GI) terhadap hasil belajar.

\section{DAFTAR PUSTAKA}

Dewi, Arianti Puspita.2011.Eksperimen Pembelajaran Matematika Dengan Strategi Group Investigation (GI) Ditinjau Dari Motivasi Berprestasi Pada Pokok Bahasan Linear Inequality With One Variable (Pada Kelas VII Semester I SMP Negeri 1 Boyolali).Skripsi. Universitas Muhamadiyah Surakarta.

Fajry, Muhammad Ilham.2012.Pengaruh Model GroupInvestigation Terhadap Prestasi Belajar Teknik Las Busur Dasar Bahasan Cacat Las Di SMK Negeri 1 Purworejo Tahun Ajaran 2011/2012. Skripsi.Universitas Negeri Yogyakarta.

Handayani, Penti.2010.Pembelajaran Biologi dengan group investigation dancooperative integrated reading ditinjau dari minat dan kedisiplinan belajarsiswa. Terdapat dihttp://pasca.uns.ac.id/?p=672 di akses 27 jul 2010 pukul $10: 35$

Herlanti, Yanti. 2008. Tanya Jawab Seputar Penelitian dalam Pendidikan Sains. Jurusan Pendidikan IPA. Jakarta : FITK UIN Syahid.

Isjoni.2010.Cooperative Learning : Efektivitas Pembelajaran Kelompok, Alfabeta, Bandung.

Robert E, Slavin.(2008). MetodeCooperative Learning Teori, Riset dan Praktik(Bandung: Nusa Media,

Sanjaya, Wina. 2009. Strategi Pembelajaran Berorientasi Standar Proses

Pendidikan. Jakarta: Kencana Pranada Media Group.ed.1 cet.6:

Sugiyono. 2007. Statistika untuk Penelitian. Bandung : Alfabeta.

Sugiyono. 2008. Metode Penelitian Kuantitatif Kualitatif dan R\&D. Bandung : Alfabeta.

Sugiyono. 2010. Statistika untuk Penelitian. Bandung : Alfabeta.

Wahab Abdul. 2012. Biostatistik Dasar. Majene: Kutub Wacana (edisi pertama) 